\title{
English Language Teaching within the New Educational Policy of Turkey: Views of Stakeholders
}

\author{
Esim Gursoy ${ }^{1}$, Sule C. Korkmaz ${ }^{1} \&$ Ebru A. Damar ${ }^{1}$ \\ ${ }^{1}$ Education Faculty, Uludag University, Bursa, Turkey \\ Correspondence: Esim Gursoy, Uludag University, Education Faculty, Gorukle Kampus, Bursa, Turkey. E-mail: \\ esimgursoy@yahoo.com
}

Received: September 30, 2016

Accepted: December 2, 2016

Online Published: March 29, 2017

doi:10.5539/ies.v10n4p18

URL: https://doi.org/10.5539/ies.v10n4p18

\begin{abstract}
Teaching English to young learners has gained speed in the past twenty years. Many countries in Europe are offering English at the primary level as advised by the EU. The efforts to lower the age for foreign language learning have echoed in countries in Asia as well. Turkey as one of these countries has changed its educational policy in 2012 and launched the new English Language Teaching Program for grades 2-8 in 2013. Along with many changes, the new system offers EFL in the second grade. The present study not only aims to investigate the views of prospective ELT teachers towards this change, but also to compare their views with those of trainers, and English teachers who were investigated in the earlier phases of the study. The results indicate that although all three groups of participants favor an earlier start in foreign language education, there are significant differences between groups in terms of the appropriate starting time and teaching methodologies used. Teachers were indecisive as they favored both the first and second tiers to introduce a foreign language. The results have implications for policy makers, teachers, teacher trainers, and prospective teachers.
\end{abstract}

Keywords: foreign language education policy, education policy, teaching English to young learners, young learners, foreign language teaching

\section{Introduction}

The global tendency to learn foreign languages (FL) at a younger age has been of influence to the educational policies of many countries. Globally, there is a shift of economic power from public to private (Schugurensky \& Davidson-Harden, 2003). Economic liberalization accomplished via governments, international organizations and/or corporations is the result of "free market" global economy (Enever \& Moon, 2009), which in turn triggered the need for English-speaking work-force. Being the lingua franca, learning English has gained importance at the international level. The governments were forced not only by this global trend "downwards", but also by the parents, "upwards" to meet the needs of the global community (Enever \& Moon, 2009). The increased demand for learning English has led the governments to lower the starting age. Thus, many countries in Europe (Finland, France, Norway, Italy etc.) and Asia (Turkey, China, India, Taiwan etc.) made changes in their educational policies to involve English as a compulsory school subject at the primary level.

Along with the world's rapid growth as a bi/multilingual context/civilization centre, there is much consensus, in the literature, on the benefits of early language learning (ELL) for holistic development of children and early development of positive attitudes towards FLs. With a broader look, relevant research highlights that offers the possible set of benefits and opportunities. First and foremost young learners (YL) understand naturally that language is something to explore, to play with and enjoy. Moreover they have low affective filter and less anxiety (Ford, 2014; Gürsoy \& Korkmaz, 2012). They have also more time for language learning and potential to develop better pronunciation. (Edelenbos, Johnstone, \& Kubanek, 2006; Enever, 2011; Enever, Moon, \& Raman, 2009; Gürsoy, Korkmaz, \& Damar, 2013; Johnstone, 2009; Tinsley \& Comfort, 2012; Unesco, 2012). Edelenbos et al. (2006), in their review of multinational research on ELL practices, report that ELL tends to be more beneficial in that it enables YLs to develop cognitive, linguistic, and socio-emotional skills and multicultural understanding and identity. As longitudinal studies confirm learning another language fosters creativity and flexibility of young children's mind and also increases their critical thinking skills. However, there has not been much evidence whether these benefits arise from YLs' innate ability to learn a language or time and exposure advantage in the long run (Edelenbos, 2006; Unesco, 2012). 
It should be kept in mind that language awareness and communicative competence can be developed only if the appropriate policy, pedagogical and language practices are provided (Edelenbos et al., 2006; Widlok, Petravic, Org, \& Romcea, 2011).The selection of appropriate pedagogic and linguistic learning content, training and/or retraining of the language teaching staff, providing tailored physical setting (Widlok et al., 2011; Enever et al., 2009) have great importance in the success of ELL. Any language program, first and foremost, should meet the child's social, cognitive and linguistic needs and contribute to their development as a whole. Most of the success in ELL relies on language teachers. TEYL requires further qualifications on the part of the teachers that are specific to the cognitive, affective, physical abilities and characteristics of children. However, most of the countries report the lack of qualified teachers for TEYL (Enever \& Moon, 2009). Moreover, the physical environment and materials have an impact on providing child appropriate teaching and giving YLs enough opportunities to use the target language while fostering their creativity and social skills.

Due to the global demand, it has grown a tendency for many countries to make necessary adjustments in their FL instruction policies (Ford, 2014). Therefore, the introduction of English into the primary curriculum has currently been one of the major education policy developments around the world (Garton, 2014; Nguyen, 2011). Along with the recent implementations in European and Asian countries nearly half of the world countries officially start second/foreign language teaching at the age of 7 years and under (Baldauf, Kaplan, Kamwangamulu, \& Byrant, 2011; Enever \& Moon, 2009; Enever, 2011; Eurydice, 2012; Mourão \& Lourenço, 2015; Selvi, 2014).

Due to the global economic needs, Turkey, has realized a major curriculum reform in 2012. The new education reform $(4+4+4)$ which extends eight years compulsory education to 12 years, dividing the period into 4 years of primary school, 4 years of secondary school, and 4 years of high school has triggered many arguments relating to its application in the current education system. Although the new system offers many changes such as the three-tier education, one of the most striking changes was made in the foreign language education (FLE). As the age for learning English as a foreign language (EFL) has been lowered to second grade, it raised some questions in terms of how much the English language teachers are prepared for even younger learners, what their beliefs are about teaching YLs, and their classroom practices to tell a few. In addition, ideas of teacher trainers' as academicians and prospective teachers (PTs) gained importance as they are the contributors and will be the participants of the new system. As the final step of a three-stage research, the current study aims to investigate the PTs' views about the starting age and the use of appropriate methodology with young learners (YLs). In addition, it aims to compare the views of English teachers (see Gürsoy, Korkmaz, \& Damar, 2013) and teacher trainers (TTs) (see, Damar, Gürsoy, \& Korkmaz, 2013) as identified during the first two stages of the study with the PTs in the present study.

\section{The New English Language Teaching Program (ELTP)}

The new education system in Turkey entailed a transition from $8+4$ model to $4+4+4$ model, which mandated EFL to be offered at 2 nd grade that was previously compulsory for 4th grades and onwards (ELTP, 2013). The new ELTP, offered due to this change in the system, follows the principles and descriptors of the Common European Framework of Reference for Languages: Learning, Teaching, Assessment (CEFR).The new system emphasizes focus on meaning rather than form to create an authentic communicative environment thus, language learning for children shouldn't be considered as an end in itself rather a means for communication (ELTP, 2013). However, coming from a traditional background for teaching, realizing the demands of the new ELTP requires knowledge, skills, and commitment on the part of the teachers as well as the program's adaptation to exam-oriented education system. The use of traditional language teaching methodology was also underlined by previous research in the same context and pointed out as one of the reasons of failure in the implementation of the previous curriculum as well (Kırkgöz, 2007). The implementation of a curriculum largely relies on how well it is understood and implemented by teachers. The new ELTP (2013), by identifying listening and speaking as primary and reading and writing as secondary skills in 2-6 grades requires a shift of understanding and methodology.

Rather than suggesting a single method, an action-oriented approach is adopted in the new program by taking CEFR's descriptors: learner autonomy, self-assessment, and appreciation of cultural diversity (ELTP, 2013). Compulsory English lessons are offered for two classroom hours in 2nd, 3rd, and 4th grades and three hours for 5th and 6th grades (Board of Education and Discipline, 2013). Suggested materials (chants, songs, rhymes, poems, menus, maps, postcards, recipes, etc.), language functions (apologizing, asking for permission, talking about feelings, talking about likes and dislikes, etc.) and assessment types (project and portfolio evaluation, self and peer evaluation, pen and paper tests including listening and speaking, teacher observation and evaluation) (ELTP, 2013) are decided by taking children's developmental features, characteristics, language learning needs 
as well as the 'here and now' principle into consideration. Moreover, meaningful, authentic language use is underlined, which requires teachers' fluency as well as proficiency in L2.

Ideas of PTs as the new force of the profession, teacher trainers and teachers as one of the agents of change are very important in any curriculum change. A common understanding of these participants is necessary to enable the implementation of a program. Thus, the present study is the first to compare teachers, teacher trainers and prospective teachers' ideas on the new ELTP (2013) in Turkey.

\section{Methodology}

A survey research type is used in the study. The data from the earlier phases of the research will be used for comparison in addition to the ones gathered for the current research. The research aims to answer the following research questions:

1) What are the prospective teachers' views about the appropriate tier to start foreign language education?

2) What are the prospective teachers' beliefs about the use of appropriate methodologies in teaching English to young learners?

3) Are there any significant differences between English teachers', teacher trainers', and prospective teachers' views in terms of the appropriate tier to start foreign language education?

4) Are there any significant differences between English teachers, teacher trainers, and prospective teachers in terms of their beliefs about the use of appropriate methodologies in teaching English to young learners?

\subsection{Participants}

870 prospective teachers (PTs) from six large state universities in Turkey contributed to the study by filling out a questionnaire prepared by the researchers. All of the participants had taken "Foreign Language Teaching to Young Learners" course during their studies. Convenience sampling method was used to gather the data. Moreover data of 203 English teachers (Gürsoy, Korkmaz, \& Damar, 2013) working in all seven different regions of Turkey from the first phase of the study and 72 teacher trainers (Damar, Gürsoy, \& Korkmaz, 2013) working in seven different universities in different parts of Turkey, from the second phase of the study, will be used for comparison.

\subsection{Data Collection}

The questionnaire used for the data collection constituted of two sections. The first one aimed to inquire about PTs' ideas related to the starting time for FLE. This section consisted of 14 closed-ended statements and one open-ended question. The second part involved 15 statements regarding the use of appropriate techniques and methodologies with YLs and aimed to find out the PTs' views about them. The items in the second section were formed via extensive literature review related to children's characteristics, developmental theories, learning styles, and assessment techniques.

\subsection{Instrument}

A five-step scale was used in the questionnaire. 1 indicated "no idea", 2 "I definitely disagree", 3 "I disagree", 4 "I agree", and 5 "I definitely disagree". For content and face validity expert opinions from five faculty members of an ELT Department were taken by using the Lawshe technique (1975). These experts were asked to evaluate each item according to how much it measures the target construct. As a result of this evaluation, three items from the first part of the questionnaire were discarded and 14 items were left. The content validity ratio of the questionnaire was then calculated as $100 \%$ which was previously $70 \%$. After the piloting stage $(\mathrm{n}=30)$, which was done for face validity, the final version of the questionnaire was prepared and distributed to the selected universities. Both parts of the questionnaire were found reliable with .753 and .751 alpha values consecutively.

\subsection{Data Analysis}

In order to answer the first and second research questions descriptive statistics was used including frequency analysis, means and standard deviations. The demographic information was analyzed via frequency analysis.

To be able to determine the most appropriate test to reveal whether there are significant differences among the three groups, Levene's test was used to assess the equality of variances for the three variables. Based on the result of P-values, the 11 items $(3,8,9,10,12,18,19,24,27,28,29)$ had smaller values than the significance level $(\mathrm{p}<0.05)$. Therefore, a one-way between subjects ANOVA was conducted to test whether there were significant differences among the three groups to answer the third and fourth research questions. Despite knowing significant differences between the groups as a whole, the Scheffé post hoc tests method, which does not require equal group size for multiple comparisons, was run so as to interpret where the significant differences 
were.

On the other hand, Levene's test showed significant differences in the following items $(1,2,4,5,6,7,11,13,14$, $15,16,17,20,21,22,23,24,25,26,29)$, which indicates differences among the variances in the population. Hence, Kruskal-Wallis test was chosen as the nonparametric alternative to the one-way ANOVA to reveal whether there were significant differences among the three groups to answer the third and fourth research questions for the above items. In addition, Mann Whitney U test was used to indicate which groups differed from each other.

\section{Results}

\subsection{PTS' Views about the Appropriate Tier to Start FLE}

The results of the descriptive statistics with regard to the views about appropriate tier to start FLE were presented in table 1 from the most frequently agreed to the least agreed one.

Table 1. Descriptive statistics of the items regarding the appropriate tier to start FLE

\begin{tabular}{llccccc}
\hline & Items & Agree $\%$ & Disagree $\%$ & No idea $\%$ & M & SD \\
\hline 5 & First Tier + usefulness & 92.8 & 5.8 & 1.4 & 4.55 & .774 \\
10 & First Tier + provide a basis & 92.1 & 6.5 & 1.4 & 4.53 & .781 \\
1 & First Tier + start & 86.5 & 11.3 & 2.2 & 4.37 & .939 \\
4 & Second Tier + late & 85.5 & 12.1 & 2.5 & 4.35 & .985 \\
6 & Language course hours & 86.5 & 9.2 & 4.3 & 4.34 & 1.001 \\
6 & Language course hours & 86.5 & 9.2 & 4.3 & 4.34 & 1.001 \\
12 & First Tier + readiness & 87.7 & 10.1 & 2.2 & 4.26 & .887 \\
9 & Pre-school + fruitful & 82.9 & 13.7 & 3.4 & 4.24 & 1.009 \\
13 & First Tier + useless & 6 & 78.9 & 15.1 & 4.10 & 1.453 \\
3 & Pre-school + start & 74.8 & 20.1 & 5 & 4.05 & 1.150 \\
11 & Pre-school + time consuming & 7.8 & 77.6 & 14.6 & 4.03 & 1.434 \\
2 & Second Tier + start & 11 & 77 & 12 & 3.89 & 1.296 \\
8 & Second Tier + unsuccessful & 68.2 & 27.7 & 4.1 & 3.88 & 1.074 \\
7 & Intensive prep-classes & 69.7 & 21 & 9.3 & 3.81 & 1.225 \\
14 & Second Tier + readiness & 18.6 & 70.6 & 10.8 & 3.77 & 1.305 \\
\hline
\end{tabular}

With regard to the most appropriate time to start FLE, the mean scores revealed that the first tier (primary school) was the most approved time. Based on the frequency analysis, most of the PTs (92.8\%) thought that teaching a FL at the first tier would be useful and would provide a basis for children's language learning (92.1\%). Thus, the majority $(86.5 \%)$ agreed that teaching a FL should start at the first tier of the $4+4+4$ system and $87.7 \%$ agreed that children are ready to learn a FL at the first stage. In addition, $89.1 \%$ of them thought that the teaching hours of English in primary school should be increased.

Pertaining to pre-school period, the results were also positive. Namely, the frequency analysis showed that most of the PTs $(82.9 \%)$ thought that starting to teach a FL during pre-school period would be fruitful and $77.6 \%$ of them disagreed that earlier start is time consuming.

Coherently, related to the second tier of $4+4+4$ education system, most of them $(85.5 \%)$ believed that starting FL education at the second tier would be late. In accordance with this idea, $70.6 \%$ of them disagreed that children are ready to learn a FL at this stage. Moreover, more than half of the participants $(68.2 \%)$ indicated that FLE cannot be successful if it starts at this tier.

\subsection{PTs'Beliefs about the Use of Appropriate Methodologies in TEYL}

The results of the descriptive statistics with regard to the PTs' beliefs about the use of appropriate methodologies in TEYL were presented in table 2 from the most frequently agreed to the least according to their mean scores. 
Table 2. Results of the PTs' beliefs about the use of appropriate methodologies in TEYL

\begin{tabular}{|c|c|c|c|c|c|c|}
\hline & Items & Agree $\%$ & Disagree \% & No idea $\%$ & M & $\mathrm{SD}$ \\
\hline 23 & Developing positive attitudes & 97.5 & 2.1 & 3 & 4.78 & .530 \\
\hline 18 & Visual and kinesthetic activities & 98 & 1.3 & 6 & 4.76 & .540 \\
\hline 19 & Enjoyable class environment & 97.5 & 1.4 & 1 & 4.74 & .605 \\
\hline 26 & Using L2 \& body language & 96.3 & 3 & 6 & 4.65 & .627 \\
\hline 16 & Contextualized language teaching & 94.4 & 4.8 & 8 & 4.62 & .695 \\
\hline 17 & Activity-based language teaching & 98 & 1.3 & 6 & 4.61 & .645 \\
\hline 24 & Performance-based assessment & 91.6 & 5.7 & 2.8 & 4.52 & .860 \\
\hline 29 & Education system \& pen-paper exams & 89 & 9.3 & 1.7 & 4.44 & .879 \\
\hline 15 & Listening and speaking & 88.9 & 9.1 & 2 & 4.32 & .844 \\
\hline 22 & Activities are time consuming & 6.1 & 82.9 & 11.1 & 4.25 & 1.338 \\
\hline 20 & Grammar-based lang. teaching & 13.2 & 80.6 & 6.2 & 4.05 & 1.100 \\
\hline 25 & Assessing pupils via pen-paper exams & 10.9 & 79.2 & 9.8 & 3.95 & 1.226 \\
\hline 28 & Using Turkish & 14.8 & 76.4 & 8.8 & 3.90 & 1.201 \\
\hline 21 & Teaching grammar via worksheets & 13.6 & 69.5 & 6.9 & 3.82 & 1.278 \\
\hline 27 & L1 equivalence & 34 & 57.7 & 8.3 & 3.51 & 1.113 \\
\hline
\end{tabular}

The mean scores presented in table 2 indicated that the most agreed item was related to developing positive attitudes towards the FL $(\mathrm{M}=4.78)$. With regard to the following six items, nearly all of the participants (with frequencies over $90 \%$ ) believed that language should be taught via visual and kinesthetic activities within an enjoyable classroom environment. Moreover, language should be taught within a meaningful context through activities and by using simple English via visuals and body language without having the need to use Turkish. In addition, they agreed that children at those ages should be evaluated via activities and games rather than pen and paper tests.

Pertaining to assessment, most of the PTs (89\%) thought that the education system leads teachers to use pen and paper exams and $79.2 \%$ of them disagreed that children should be assessed via pen and paper exams. Correspondingly, most of the PTs $(82.9 \%)$ disagreed that teaching a FL through games, songs and activities are time consuming, should focus on grammar teaching $(80.6 \%)$ and L1 use (76.4\%). Moreover, $69.5 \%$ of them disagreed that grammar should be taught through worksheets rather than games and activities. The PTs agreed the least on the use of L1 ( $\mathrm{M}=3.51)$. Only slightly more than half of the participants $(57.7 \%)$ disagreed that teachers should give L1 meaning as well.

\subsection{Comparison of PTS, English Teachers, and TTs with regard to the start of FLE}

Based on the Levene's test result, either a one-way ANOVA or Kruskal-Wallis test was used to find out the differences among groups about the items related to the appropriate tier to start FL instruction.

A one-way ANOVA results revealed that there were significant differences at the $\mathrm{p}<.05$ level for the items 8 [F $(2.1134)=67.801, \mathrm{p}=.000]$, indicating that starting FLE at the second tier will be unsuccessful and item 12 $[\mathrm{F}(2.1133)=3.594, \mathrm{p}=.028]$, indicating positive ideas about students' readiness at the first tier.

Scheffé posthoc comparisons showed significant differences regarding item 8 between the PTs and the teachers $(\mathrm{p}=.00)$, between the PTs and the TTs $(\mathrm{p}=.02)$, and between the teachers and TTs $(\mathrm{p}=.03)$. Accordingly, mostly the PTs $(M=3.88)$, then the TTs $(M=3.41)$, finally the teachers $(M=2.91)$ thought that starting FL instruction at the second tier of primary school would have unsuccessful results. With regard to students' readiness at first tier (item 12), the Scheffé result showed a significant difference between the PTs and the teachers $(\mathrm{p}=.48)$. The teachers agreed $(M=4.3)$ more than the PTs $(M=4.26)$ that children are ready to learn a FL at the first tier.

When the results of Kruskal Wallis test were taken into account, significant differences were found for items 1, 2, $4,7,11,13,14$ related to the appropriate tier to start FL instruction. Table 3 below indicates the results. 
Table 3.The results of Kruskal Wallis test to display the significant differences among groups about the appropriate tier to start FLE

\begin{tabular}{lccccccc}
\hline Items & 1 & 2 & 4 & 7 & 11 & 13 & 14 \\
\hline Chi-Square & 7.431 & 19.641 & 13.186 & 21.993 & 9.609 & 24.684 & 14.310 \\
Df & 2 & 2 & 2 & 2 & 2 & 2 & 2 \\
Asymp. Sig. & .024 & .000 & .001 & .000 & .008 & .000 & .001 \\
\hline
\end{tabular}

$\mathrm{p}<.05$.

Mann-Whitney U test results between the PTs and the teachers revealed statistically significant differences for items 1, 2, 4, 7, 11, 13, 14 (Table 4); between the PTs and the TTs for items 1 and 7 (Table 4); between the teachers and the TTs for items $2,4,7,13,14$.

Table 4. Comparison of PTs and the teachers about the appropriate tier to start FLE

\begin{tabular}{|c|c|c|c|c|c|c|c|c|}
\hline Items & Groups & $\mathrm{N}$ & M & Mdn & Mean Rank & $\mathrm{U}$ & Z & $\mathrm{P}$ \\
\hline \multirow{2}{*}{$\begin{array}{l}\text { First Tier }+ \text { starting time } \\
\text { (1) }\end{array}$} & PTs & 867 & 4.37 & 5 & 527.52 & \multirow{2}{*}{81086.0} & \multirow{2}{*}{-2.010} & \multirow{2}{*}{.044} \\
\hline & Teachers & 203 & 4.51 & 5 & 569.56 & & & \\
\hline \multirow{2}{*}{$\begin{array}{l}\text { Second Tier }+ \text { starting } \\
\text { time (2) }\end{array}$} & PTs & 861 & 3.89 & 4 & 514.73 & \multirow{2}{*}{72089.0} & \multirow{2}{*}{-4.163} & \multirow{2}{*}{.000} \\
\hline & Teachers & 203 & 4.35 & 5 & 607.88 & & & \\
\hline \multirow{2}{*}{ Second Tier + late (4) } & PTs & 848 & 4.35 & 5 & 512.03 & \multirow{2}{*}{74226.0} & \multirow{2}{*}{-3.424} & \multirow{2}{*}{.001} \\
\hline & Teachers & 202 & 4.58 & 5 & 582.04 & & & \\
\hline \multirow{2}{*}{$\begin{array}{l}\text { Intensive prep-classes } \\
(7)\end{array}$} & PTs & 864 & 3.81 & 4 & 516.48 & \multirow{2}{*}{72558.0} & \multirow{2}{*}{-4.032} & \multirow{2}{*}{.000} \\
\hline & Teachers & 203 & 4.11 & 5 & 608.57 & & & \\
\hline \multirow{2}{*}{$\begin{array}{l}\text { Pre-school }+ \text { time } \\
\text { consuming (11) }\end{array}$} & PTs & 868 & 4.03 & 5 & 548.73 & \multirow{2}{*}{77051.0} & \multirow{2}{*}{-3.070} & \multirow{2}{*}{.002} \\
\hline & Teachers & 203 & 3.97 & 4 & 481.56 & & & \\
\hline \multirow{2}{*}{ First Tier + useless (13) } & PTs & 869 & 4.10 & 5 & 555.70 & \multirow{2}{*}{71521.50} & \multirow{2}{*}{-4.745} & \multirow{2}{*}{.000} \\
\hline & Teachers & 203 & 4.09 & 4 & 454.32 & & & \\
\hline \multirow{2}{*}{$\begin{array}{l}\text { Second Tier }+ \text { readiness } \\
\text { (14) }\end{array}$} & PTs & 867 & 3.77 & 4 & 521.01 & \multirow{2}{*}{75433.50} & \multirow{2}{*}{-3.342} & \multirow{2}{*}{.001} \\
\hline & Teachers & 203 & 4.13 & 4 & 597.41 & & & \\
\hline
\end{tabular}

$\mathrm{p}<.05$.

The results are contradictory in terms of the teachers' answers to the start of FLE in that they favored both the first and second tiers more than the PTs. However, although they agreed more than the PTs that students are ready to learn a FL at the second tier, they also claimed that the second tier is late. On the other hand, PTs have stronger views than the teachers that starting FLE at pre-school is time consuming and FLE at the first phase is useless.

When comparing PTs and TTs, the results of the Mann-Whitney U test revealed significant differences regarding two issues (Table 5). Thus, opinions about starting FL instruction at the first tier of the $4+4+4$ system were stronger for the TTs than the PTs. The PTs favored a one-year intensive preparation-class before starting secondary school more than the TTs.

Table 5. Comparison of the PTs and the TTs about the appropriate tier to start FLE

\begin{tabular}{|c|c|c|c|c|c|c|c|c|}
\hline Items & Groups & $\mathrm{N}$ & M & Mdn & Mean Rank & $\mathrm{U}$ & Z & $\mathrm{P}$ \\
\hline \multirow{2}{*}{$\begin{array}{l}\text { First tier }+ \text { starting } \\
\text { time (1) }\end{array}$} & PTs & 867 & 4.37 & 5 & 465.00 & \multirow{2}{*}{26875.00} & \multirow{2}{*}{-2.042} & \multirow{2}{*}{.041} \\
\hline & TTs & 71 & 4.60 & 5 & 524.48 & & & \\
\hline \multirow{2}{*}{$\begin{array}{l}\text { Intensive prep-classes } \\
\text { (7) }\end{array}$} & $\mathrm{PTs}$ & 864 & 3.81 & 4 & 472.34 & \multirow{2}{*}{26062.50} & \multirow{2}{*}{-2.014} & \multirow{2}{*}{.044} \\
\hline & TTs & 70 & 3.47 & 4 & 407.82 & & & \\
\hline
\end{tabular}
$\mathrm{p}<.05$.

The results of the Mann-Whitney $U$ test also revealed significant differences between the teachers and the TTs regarding five items (Table 6$)$. Thus, the teachers $(M=4.35)$ agreed more than the TTs $(M=3.61)$ that secondary 
school is the most appropriate time to start teaching a FL. Moreover, the teachers $(M=4.13)$ believed more than the TTs $(M=3.60)$ that children are more ready to learn a FL at the second tier. The TTs $(M=4.19)$ agreed more than the teachers $(\mathrm{M}=4.09)$ that teaching a FL at the first tier is not effective. However, it is surprising that the teachers $(\mathrm{M}=4.58)$ agreed more than the TTs $(\mathrm{M}=4.26)$ that starting FLE at the second tier of $4+4+4$ education system would be late. Finally, the teachers $(\mathrm{M}=4.11)$ believed more than TTs $(\mathrm{M}=3.47)$ that providing a one-year intensive preparation-class before starting secondary school is important for learners' FLL.

Table 6. Comparison of the teachers and the TTs about the appropriate tier to start FLE

\begin{tabular}{|c|c|c|c|c|c|c|c|c|}
\hline Items & Groups & $\mathrm{N}$ & $\mathrm{M}$ & Mdn & Mean Rank & $\mathrm{U}$ & Z & $\mathrm{p}$ \\
\hline \multirow{2}{*}{$\begin{array}{l}\text { Second tier }+ \text { starting } \\
\text { time }(2)\end{array}$} & Teachers & 203 & 4.35 & 5 & 145.33 & \multirow{2}{*}{5413.50} & \multirow{2}{*}{-3.243} & \multirow{2}{*}{.001} \\
\hline & TTs & 70 & 3.61 & 4 & 112.84 & & & \\
\hline \multirow{2}{*}{ Second tier + late (4) } & Teachers & 202 & 4.58 & 5 & 142.37 & \multirow{2}{*}{5682.50} & \multirow{2}{*}{-2.792} & \multirow{2}{*}{.005} \\
\hline & TTs & 69 & 4.26 & 5 & 117.36 & & & \\
\hline \multirow{2}{*}{$\begin{array}{l}\text { Intensive prep-classes } \\
(7)\end{array}$} & Teachers & 203 & 4.11 & 5 & 147.11 & \multirow{2}{*}{5053.50} & \multirow{2}{*}{-3.840} & \multirow{2}{*}{.000} \\
\hline & TTs & 70 & 3.47 & 4 & 107.69 & & & \\
\hline \multirow{2}{*}{ First tier + useless (13) } & Teachers & 203 & 4.09 & 4 & 128.68 & \multirow{2}{*}{5416.50} & \multirow{2}{*}{-3.412} & \multirow{2}{*}{.001} \\
\hline & TTs & 71 & 4.19 & 5 & 162.71 & & & \\
\hline \multirow{2}{*}{$\begin{array}{l}\text { Second tier }+ \text { readiness } \\
\text { (14) }\end{array}$} & Teachers & 203 & 4.13 & 4 & 146.03 & \multirow{2}{*}{5474.50} & \multirow{2}{*}{-3.215} & \multirow{2}{*}{.001} \\
\hline & TTs & 71 & 3.60 & 4 & 113.11 & & & \\
\hline
\end{tabular}
$\mathrm{p}<.05$.

\subsection{Comparison of Groups Rlated to their Beliefs about the Use of Appropriate Methodologies in TEYL}

The one-way ANOVA results revealed that there were significant differences at the $\mathrm{p}<.05$ level for item 28 which is about the use of English $[\mathrm{F}(2.1123)=5.204, \mathrm{p}=.006]$. Scheffé posthoc comparisons indicated the significant difference between the PTs and the teachers $(\mathrm{p}=0.07)$ with regard to the use of English in the classroom. Accordingly, the PTs $(\mathrm{M}=3.90)$ more than the teachers $(\mathrm{M}=.60)$ agreed that students would not be able to understand lessons presented in English.

Based on the results of Kruskal Wallis test, significant differences were found for items 16, 20, and 26 that were related to the participants' beliefs about the use of appropriate methodologies in TEYL. Table 7 below indicates the results.

Table 7. The results of Kruskal Wallis test results

\begin{tabular}{lccc}
\hline Items & 16 & 20 & 26 \\
\hline Chi-Square & 19.597 & 10.464 & 24.860 \\
Df & 2 & 2 & 2 \\
Asymp. Sig. & .000 & .005 & .000 \\
\hline
\end{tabular}

$\mathrm{p}<.05$.

Mann-Whitney U test results between the PTs and the teachers revealed statistically significant differences for items 16, 20, 26 (Table 8); between the PTs and the TTs for item 26; and between the teachers and the TTs for item 16. 
Table 8. Comparison of the PTs' and the teachers' beliefs about the use of appropriate methodologies in TEYL

\begin{tabular}{|c|c|c|c|c|c|c|c|c|}
\hline Items & Groups & $\mathrm{N}$ & $\mathrm{M}$ & $\begin{array}{l}\text { Mean } \\
\text { Rank }\end{array}$ & $\mathrm{U}$ & $\mathrm{Z}$ & $\mathrm{p}$ & Mdn \\
\hline \multirow{2}{*}{$\begin{array}{l}\text { Contextualized Language } \\
\text { Teaching (16) }\end{array}$} & PTs & 858 & 4.62 & 545.16 & \multirow[b]{2}{*}{74934.50} & \multirow[b]{2}{*}{-3.816} & \multirow[b]{2}{*}{.000} & 5 \\
\hline & Teachers & 203 & 4.43 & 471.14 & & & & 5 \\
\hline \multirow{2}{*}{$\begin{array}{l}\text { Grammar-based Language } \\
\text { Teaching (20) }\end{array}$} & PTs & 856 & 4.05 & 517.01 & \multirow{2}{*}{75765.50} & \multirow{2}{*}{-2.846} & \multirow{2}{*}{.004} & 4 \\
\hline & Teachers & 201 & 4.31 & 580.06 & & & & 4 \\
\hline \multirow{2}{*}{$\begin{array}{l}\text { Using L2 \& Body Language } \\
\text { (26) }\end{array}$} & PTs & 860 & 4.65 & 548.15 & \multirow{2}{*}{73401.0} & \multirow{2}{*}{-4.333} & \multirow{2}{*}{.000} & 5 \\
\hline & Teachers & 203 & 4.46 & 463.58 & & & & 5 \\
\hline
\end{tabular}
$\mathrm{p}<0.05$.

The results of the Mann- Whitney $U$ test presented in table 8 revealed significant differences between the PTs and the teachers related to three items. Accordingly, the PTs believed more than the teachers that YLs should be taught English within a meaningful context and via visuals and body language without having the need to use Turkish. Correspondingly, the teachers agreed more than the PTs that language teaching in primary school should focus on grammar.

The results of Mann-Whitney's U test between the PTs and the TTs revealed a significant effect of Group (The mean ranks of the group of PTs and TTs were 470.05 and 386.37 respectively; $U=23609 . Z=-3.077 \mathrm{p}=, 002$ ) for item 26. The means of the groups were 4.65 (PTs) and 4.35 (TTs) and the medians of the groups were 5.00. Based on this result, the PTs believed that language should be taught by using simple English via visuals and body language without having the need to use Turkish more than the TTs as similar to their comparison with teachers.

The results of Mann-Whitney's U test between the group of teachers and the group of the TTs revealed a significant effect of Group (The mean ranks of the group of teachers and TTs were 127.72 and 160.71 respectively; $\mathrm{U}=5222 . \mathrm{Z}=-3.547 \mathrm{p}=.000$ ) for item 16.The medians of the groups were 5.00. Based on the result, the TTs $(M=4.77)$ believed that young learners should be taught English within a meaningful context more than the teachers $(\mathrm{M}=3.43)$.

\section{Discussions}

The recent modifications in Turkish education system with the $4+4+4$ model brought changes in FLE program by lowering the starting age to second grade. The need for dealing with even younger language learners created concerns and questions in education circles such as teacher qualifications and competencies required at this level. Nuremberg Recommendations on Early Foreign Language Learning (Widlok, et al., 2011) and European Commission's report on Education and Training (n.d.) identified the teacher qualifications and contextual requirements for ELL; however, as with any curriculum innovation, in addition to providing necessary conditions for learning, it is important to harken the stakeholders (teachers, teacher trainers, prospective teachers, parents, students) that will be affected by those changes. With this aim in mind the present study focused on PTs, teachers, and TTs opinions regarding the starting age for FLE and the use of appropriate methodologies with YLs.

The results regarding PTs beliefs about the appropriate tier to start FLE revealed that the majority opt for an early start at the primary school and considered the 2 nd tier late. The results were also promising that most of the participants had positive ideas for even an earlier start at pre-school. In this sense PTs ideas are in-line with the European Commission (EC, 2011; 2015a; 2015b; Enever \& Moon, 2009).

One of the aims of early FLE is to help children gain positive attitudes toward the language (EC, 2015a). Having limited cognitive abilities and metacognitive awareness children are unable to learn the structure of the language. Thus, language is a means of communication to exchange ideas, beliefs, and thoughts. Having no reason to learn another language in a FL context, it becomes important to teach the language similar to everyday activities that children are engaged with and that are involving, meaningful, and fun. Language functions, topics, and activities that are selected from the here and now as well as meaning-focused interaction will help children to develop positive attitudes toward the language and create a desire to continue with FLE. In this sense, it is promising that almost all of the participants considered developing positive attitudes as important when teaching 6-11 years old children.

Overall, PTs beliefs seem to be appropriate regarding children's characteristics and cognitive abilities. Children are predominantly visual and kinesthetic, they like to have fun, they are meaning-focused, and as they are still 
developing cognitively they cannot understand abstract rules (Gürsoy, 2011; Gürsoy \& Korkmaz, 2012; Halliwell, 1992; Moon, 2000), thus, almost all PTs agreed that TEYL should carry these features. Similarly, most of the participants disagreed with pen-paper assessment, however, they indicated their concern that the education system leads them toward such type of assessment. Interestingly, however, although most of them disagreed with the use of Turkish to teach English to YLs, the number of people who disagreed with the use of L1 equivalence along with the L2 was only the half of the PTs. This can be interpreted as although the PTs do not consider using Turkish all the time they are dubious about giving L1 translation after L2 input.

The findings from the comparison of groups revealed some contradictory results in terms of the starting age for FLE. For example, in comparing teachers with PTs, although the teachers agreed more than the PTs that children are ready to learn L2 in primary school, FLE should start at the first tier, and that the second tier would be late, they also claimed more strongly than the PTs that children are also ready to learn L2 in the second tier and FLE should start at secondary school. These contradictory results from the teachers may be an indication of a need for knowledge about developmental differences between children at different age groups and reasons for ELL. This undecidedness is also reflected in FLE in pre-school and the inclusion of the one-year intensive English program before the $2^{\text {nd }}$ tier. Teachers didn't consider FLE as time consuming in pre-school as much as the PTs did and they believed more strongly from the PTs that intensive program is necessary. When compared to PTs, the teachers do not seem to have an established idea concerning the starting age and effectiveness of FLE at a certain tier. These confusing results may have several reasons that need further investigation: First, former professional experiences of working at different tiers, or personal experiences as a learner might have an impact on this situation. Second, teachers" understanding of "success" can have a role in having positive ideas about all tiers. "Success" in primary school is helping children enjoy the language learning process, develop positive attitudes, and classroom interactional competence with focus on listening and speaking skills. However, at upper grade levels it might mean to be successful at central language exams, understanding the abstract concepts such as grammar, and developing communicative competence. Depending on the age of the learner different goals can be attained and in that perspective starting at different tiers might seem plausible. Last, as frequently debated in the field, the advantages of an early start might not be clear for teachers. Besides being a global trend, one of the advantages of ELL is to increase the duration of exposure to the L2 (Enever \& Moon, 2009). Moreover, learning certain aspects of language is easier at certain age intervals. At the early years, children benefit from learning the phonological aspects (Johnstone, 2009), as they grow older (after age 11-12) they can develop the syntactic and morphological aspects. Thus, an early start will help children to use and benefit all facets of the language as they graduate from high school. All in all, this situation requires further investigation with teachers.

The comparison between PTs and TTs, on the other hand, showed that although both groups favored an early start at the 1st tier, TTs had stronger views about it. What's more, both groups had moderately strong views regarding a one-year intensive English program before the 2nd tier, yet PTs supported the idea more than the TTs. Looking at the results teachers were the most supportive group of an intensive English program, whereas, PTs, and TTs supported the idea at a moderate level. The opinions of the participants are important as the Ministry of National Education (MoNE) is planning to implement intensive English classes gradually, starting with voluntary private schools (Çakmakçı, 2015). The MNE has announced that (Hürriyet, 2015) without changing the $4+4+4$ system the $5^{\text {th }}$ grade will be an intensive English program after completing necessary infrastructure in state schools. The education, as reported, will be similar to those of former Anatolian high schools, which proved to be successful in FLE (Hürriyet, 2015). Thus, 22-23 hours of 35-hour weekly schedule will be spared for language education (Çakmakçı, 2015). The findings of the present study indicate that though teachers support the MoNE's decision for intensive FLE, it might because of the aforementioned inadequate infrastructure that PTs and TTs display moderate degree of agreement. Yet, further investigation is necessary to identify the underlying reasons.

TTs and teachers also differed in terms of their choices regarding the start of FLE. When compared to TTs, teachers agreed more that FLE should start at the second tier. Among the three groups teachers agreed more with the idea to start at the 2nd tier. PTs and TTs followed consecutively. The reason why teachers favor the 2nd tier might be due to being a practitioner. As practitioners, teachers are experiencing the difficulties of TEYL more than the other groups. TEYL is, no doubt, more demanding than teaching older age groups in that it requires extra effort due to children's characteristics, limited cognitive abilities, and metacognitive awareness. The teachers need to be physically more active and prepare more visual and kinesthetic activities considering that children have low attention span, get bored easily and do not have a reason for learning another language in a FL context (Gürsoy, 2012; Gürsoy, 2011, Haznedar, 2014; Mourão \& Lourenço, 2014). Being a theoretician, TTs and being inexperienced, PTs might have a disagreement with the issue. Interestingly, although both the teachers 
and the TTs agreed that 2 nd tier is late for FLE, teachers had stronger views. This is, again, another contradiction on the part of the teachers. Although they think that secondary school is late for a start, the challenges of teaching at primary school might cause them to opt for secondary school.

Another confliction can be seen in teachers and TTs agreement on the idea that FLE in primary school is useless. TTs agreed with the idea more than the teachers. Though unexpected, there might be several reasons so as to why TTs consider the efforts in primary school useless: First, although children learn fast due to their limited cognitive abilities and lack of abstract thinking they also forget fast. Thus, there is a great chance that children will forget some of the information they received by the time they are at secondary school. Second, for an early start to be successful there are certain conditions to be met. It is often advised that L2 instruction is continuous and introduced at least five classroom hours a week so that there is one FL lesson every day (EC, n.d.). Moreover, the classroom conditions such as the level of input provided by the teacher, activities selected, materials used, language focus (meaning rather than form), skills emphasized (listening and speaking rather than reading and writing), topics selected (from the here and now), contextualization and the physical conditions (number of students in the classroom, space for kinesthetic activities etc.) should be provided appropriately to meet the needs of YLs. Last but not least, teachers' language fluency and ability to adjust their teacher talk to children's level are important criteria as the FLE to YLs focuses more on oral communication skills than form-focused grammar instruction. TTs, noticing that these conditions are not or cannot be provided currently in all Turkish schools (language lessons offered for 2-3 hours a week (ELTP, 2013), crowded classes, rather small classrooms ...), might consider FLE in primary school as wasted efforts.

The groups' ideas also differed from each other in terms of their belief about the use of appropriate methodologies in TEYL. PTs had a strong idea that children won't be able to understand lessons presented in L2 than the teachers. The result is interesting as the PTs are provided with the information contrary to this belief throughout their education. However, it is also known that earlier experiences are stronger than newly received information that is not experienced yet (Gürsoy \& Korkmaz, 2012; İnözü, 2011, Kaplan, Baldauf, \& Kamwangamalu, 2011). Thus, it is possible that pre-service education was not enough to change PTs ideas about the issue.

Both the PTs and teachers agreed with the importance of contextualization in language teaching, yet PTs were more passionate than the teachers, which is promising. However, the TTs were the group who believed in the importance of contextualization more than the other groups. On the other hand, PTs and teachers claimed that FLE in primary school should be grammar focused with teachers having a stronger idea. This result is important in terms of its implications. The recent English Language Teaching Program (ELTP, 2013) strongly emphasized meaning-focused instruction as it is concerned with language functions rather than grammar items to be achieved. Moreover, the essence of TEYL is far from grammar-oriented approaches in which the language is the target to be achieved rather than a medium for communication. On top of that, considering children's abilities, a focus on grammar is far from being a realistic objective. However, one explanation of this finding is that having a traditional language learning experience and living in an exam-oriented educational context PTs and teachers might still consider grammar as primary concern. Yet, a pleasing finding is that both teachers and PTs claim that it is possible to teach L2 via L2 with the use of visuals and body language without much need to use L1.

\section{Conclusions}

The upward and downward pressures on governments to lower the age of FLE manifested itself in rapid policy changes all around the globe. However, in most cases these changes were faster than the required planning for successful implementation (Ali, Hamid, \& Moni, 2011, Baldauf et al., 2011, Enever \& Moon, 2009; Garton, Copland, \& Burns, 2011; Gimenez, 2009; Lee, 2009). Turkey having gone through such a policy change in 1997 by offering English as a compulsory school subject at the 4th grade (Gürsoy et al., 2013; MoNE, 1997), implemented a recent change by lowering the starting age to 2 nd grade as a result of $4+4+4$ education model in 2012. This change required even more language teachers to be qualified to teach younger learners and raised concerns regarding their readiness to teach. Launched in 2013, the new ELTP left the teachers, TTs, PTs with a lot of questions in mind. Therefore, the present study aims to report on PTs ideas on the starting age and use of appropriate methodologies with YLs. In addition, by using earlier findings from teachers and TTs as part of the same research project, it aimed to compare the stakeholders' views on the aforementioned issues.

The findings of the present study indicated that PTs have positive opinions for an early start as with the teachers (Gürsoy et al., 2013) and TTs (Damar et al., 2013). However, although all parties had positive opinions, a detailed comparison of these groups revealed some important findings. Teachers opted both for first and second tier as a start for FLE, being most supportive of a start in 2nd tier. In the same vein, they also strongly favored an 
intensive English program at 5th grade. The findings require further investigation as the teachers do not have a clear option for the starting age, which might be due to some of the reasons mentioned in the discussion. Yet, as is, the findings require a need for in-service preparation for the new ELTP, and information about the reasons for an early start, as it was also suggested by Gürsoy et al. (2013).

In terms of a one-year intensive English program, which MoNE is working for its gradual implementation teachers were more supportive than the other groups. It is promising that teachers will embrace the new implementation. As in every curriculum innovation or renovation the ideas of stakeholders that are affected from the consequences is important.

All groups, but TTs more than the other groups, considered FLE in the first tier as useless even though all favored an early start in primary school. Although as important as it is to understand the global demands and objectives of early FLE, it is important to provide the necessary conditions for successful implementations. As Nikolov and Djigunović (2006) indicate: 'Most countries accept the folk wisdom and findings from L2 contexts without considering questions like the amount and quality of exposure to L2, teachers' competences and motivation, classroom methodology and continuity of programs' (p. 243). Thus, teachers', TTs', and PTs' concerns regarding the effectiveness of primary EFL may lie behind how much/well these conditions are met in Turkey. From this stand point, for an effective TEYL all countries including Turkey need to improve the conditions via providing physical requirements, in-service training of teachers, pre-service training of PTs, and organization of FL hours in primary curriculum so that it meets children's characteristics and cognitive development.

To sum up, although Turkey's efforts to meet the global demand on TEYL are remarkable, a great deal of investment is required in pre- and in-service teacher training. Thus, the next step after the recent ELTP is to speed up the process to improve TEYL conditions.

\section{References}

Ali, N. L., Hamid, M. O., \& Moni, K. (2011). English in primary education in Malaysia: policies, outcomes and stakeholders' lived experiences. Current Issues in Language Planning, 12(2), 147-166. https://doi.org/10.1080/14664208.2011.584371

Bakan Avcı'dan hazırlık sınıf açıklaması: Önce pilot uygulama başlatacağız. (2015). Hürriyet, Retrieved from http://www.hurriyet.com.tr/egitim/28732063.asp

Baldauf, R.B., Kaplan, R.B., Kamwangamalu, N., \& Bryant, P. (2011). Success or failure of primary second/foreign language programmes in Asia: what do the data tell us? Current Issues in Language Planning, 12(2), 309-323. https://doi.org/10.1080/14664208.2011.609715

Board of Education and Discipline, (2013). [Talim ve Terbiye Kurulu Karar1 28. May 2013.]

Çakmakçı, N. (2015). Secondary school 5th grades are becoming foreign language preparatory classes [Ortaokul 5'ler yabanci dil hazırlik sinıfi oluyor]. Hürriyet. Retrieved from http://www.hurriyet.com.tr/ortaokul-5-ler-yabanci-dil-hazirlik-sinifi-oluyor-28720019

Damar, E. A., Gürsoy, E., \& Korkmaz, Ş. Ç. (2013). Teaching English to young learners: Through the eyes of EFL teacher trainers. ELT Research Journal, 2(3), 95-110.

Edelenbos, P., Johnstone, R., \& Kubanek, A. (2006). The main pedagogical principles underlying the teaching of languages to very young learners, languages for the children of Europe, published research, good practice \&main principles. London: European Commission. https://doi.org/10.1515/9783110948752

Enever, J. (2011). ELLiE: Early language learning in Europe. London: British Council.

Enever, J., \& Moon. J. (2009). New global contexts for teaching primary ELT: Change and challenge. In J. Enever, J. Moon, \& U. Raman (Eds.), Young Learner English language policy and implementation: International perspectives (pp. 5-21). Reading: Garnet Education. https://doi.org/10.1111/j.1467-971X.2012.01766.x

English Language Teaching Program for Primary and Secondary Schools. (2013). Ministry of National education, Ankara, Turkey [İlköğretim Kurumları (İlkokullar ve Ortaokullar) İngilizce Dersi (2, 3, 4, 5, 6, 7 ve 8. Sınıflar) Öğretim Programı, Milli Eğitim Bakanlığı, Ankara, Türkiye].

European Commision. (2015a). Retrieved from http://ec.europa.eu/languages/policy/learning-languages/earlylanguage-learning_en.htm

European Commision. (2015b). Retrieved from http://ec.europa.eu/languages/policy/learning-languages/index_ 
en.htm

European Commision. (n.d). Education and Training Foreign Languages in Primary and Pre-school Education: Context and Outcomes A summary. Retrieved from http://p21208.typo3server.info/fileadmin/content/assets/ eu_language_policy/key_documents/studies/foreign_en.pdf

European Commission. (2011). Language Learning at Pre-primary School Level: Making it Efficient and Sustainable. Policy Handbook. Commission Staff Working Paper. European Strategic Framework for Education and Training (ET 2020).

Eurydice. (2012). Key data on teaching languages at school in Europe, Brussels: Education, audiovisual and culture executive agency. Retrieved from http://eacea.ec.europa.eu/education/eurydice/documents/key-dataseries/143en.pdf

Garton, S. (2014). Unresolved issues and new challenges in teaching English to young learners: The case of South Korea, Current Issues in Language Planning, 15(2), 201-219. https://doi.org/10.1080/14664208.2014.858657

Garton, S., Fiona., C., \& Burns, A. (2011). Investigating global practices in teaching English to young learners. ELT Research Papers, 1, 35-67.

Gimenez, T. (2009). English at primary school level in Brazil: Challenges and perspectives. In J. Enever, J. Moon, \& U. Raman (Eds.), Young Learner English language policy and implementation: International perspectives (pp. 53-59). Reading: Garnet Education.

Gürsoy, E. (2011). The Critical period hypothesis revisited: The implications for current language teaching to young learners. Journal of Language Teaching and Research, 2, 757-762. https://doi.org/10.4304/jltr.2.4.757-762

Gürsoy, E. (2012). Music and puppets. In E. Gürsoy, \& A. Arikan (Eds.),Teaching English to young learners: An activity-based guide for prospective teachers (pp. 27-339). Ankara: Egiten Kitap.

Gürsoy, E., \& Korkmaz, Ş. Ç. (2012). Teaching young learners: The role of theory on practice. ELT Research Journal, 1(2), 109-119.

Gürsoy, E., Korkmaz, Ş. Ç., \& Damar, E. A. (2013). Foreign language teaching within 4+4+4 education system in Turkey: Language teachers' voices. Eurasian Journal of Educational Research, 53(A), 59-74.

Halliwell, S. (1992). Teaching in English in the primary classroom. Harlow: Longman.

Haznedar, B. (2014). Cognitive and linguistic aspects of learning a second language in the early years. In S. Mourã, \& M. Lourenço (Eds.), Early Years Second Language Education: International Perspectives on Theory and Practice (pp. 14-28). Oxford: Routledge.

İnözü, J. (2011). Beliefs about foreign language learning among students training to teach English as a foreign language. Social Behavior and Personality, 39, 645-654. https://doi.org/10.2224/sbp.2011.39.5.645

Johnstone, R. (2009). An early start: What are the key conditions for generalized success? In J, Enever, J. Moon, \& U. Raman (Eds.), Young Learner English language policy and implementation: International perspectives (pp. 31-41). Reading: Garnet Education.

Kaplan, R. B., Baldauf, R. B. Jr., \& Kamwangamalu, N. (2011). Why educational language plans sometimes fail. Current Issues in Language Planning, 12(2), 105-124. https://doi.org/10.1080/14664208.2011.591716

Kirkgöz, Y. (2007). Language planning and implementation in Turkish primary schools. Current Issues in Language Planning, 8(2), 174-191. https://doi.org/10.2167/cilp114.0

Lawshe, C. H. (1975). A Quantitative approach to content validity. Personnel Psychology, 28, 563-575. https://doi.org/10.1111/j.1744-6570.1975.tb01393.x

Lee, W. K. (2009). Primary English language teaching (ELT) in Korea: Bold risks on the National Foundation. In J, Enever, J. Moon, \& U. Raman (Eds.), Young Learner English language policy and implementation: International perspectives (pp. 95-102). Reading: Garnet Education.

Moon, J. (2000). Children learning English. Oxford: Macmillan-Heinemann.

Mourão, S., \& Lourenço, M. (2015). Early years second language education: International perspectives on theory and practice. Abingdon: Routledge.

Nguyen, H. T. M. (2011). Primary English language education policy in Vietnam: Insights from implementation. 
Current Issues in Language Planning, 12(2), 225-249. https://doi.org/10.1080/14664208.2011.597048

Nikolov, M., \& Djigunović, J. M. (2006). Recent research on age, second language acquisition, and early foreign language learning, Annual Review of Applied Linguistics, 26, 234-260. https://doi.org/10.1017/S0267190506000122

Schugurensky, D., \& Davidson-Harden, A. (2003). From Córdoba to Washington: WTO/GATS and Latin American Education. Globalisation, Societies and Education, 1(3), 321-357. https://doi.org/10.1080/1476772032000141799

Tinsley, T., \& Comfort, T. (2012). Lessons from abroad: International review of primary languages. Reading: CfBT.

Turkish Ministry of National Education (MoNE) [Milli Eğitim Bakanlığı (MEB)]. (1997). Primary education grades 4 and 5 foreign language (English) curriculum [ilköğretim okulu 4.ve 5. Sınıf yabancı dil öğretim programı], MoNE official Journal [Milli Eğitim Bakanlığı Tebliğler Dergisi], 248,606-624.

Unesco. (2012). Why language matters for the millennium development goals. Bangkok: UNESCO.

Widlok, B., Petravić, A., Org, H., \& Romcea, R. (2011). Nuremberg recommendations on early foreign language learning (Revised edition). London: Goethe Institut.

\section{Notes}

Note 1. Phase 1 and 2 of the study were published earlier in other journals (see Damar, Gürsoy, \& Korkmaz, 2013 and Gürsoy, Korkmaz, \& Damar, 2013). Additional information regarding these phases can be found by referring to these articles given in the reference list.

Note 2. Detailed methodological information regarding the earlier phases of the study can be found in the cited articles.

\section{Copyrights}

Copyright for this article is retained by the author(s), with first publication rights granted to the journal.

This is an open-access article distributed under the terms and conditions of the Creative Commons Attribution license (http://creativecommons.org/licenses/by/4.0/). 